in Asia. No fossil pine remains have been found in the tropics or south of the equator. From Cretaceous times Mexico has become a secondary centre of proliferation of diploxylon pine species, owing to its wide range of habitats within short distances.

Many small scale outline maps and excellent photographs cover the distribution and appearance of 105 species, the areas where hybridization between species has occurred and the world pine regions. Some species have greatly expanded their distribution since the ice ages, for example Scots pine; others are senile and isolated in parts of California and elsewhere; some can be crossed easily with related members of the genus although widely separated for many million years; others are difficult to hybridize.

There are chapters on genetic aspects, on morphology and reproduction, and on physiology and ecology. Much is still unknown and, interested in tropical pines, I found no explanation of the grass stage of seedlings common to several species or apical dominance so characteristic of Pinus caribaea and some others when grown in favourable conditions.

The relatively new study of the chemical aspects of pine cell contents has been a special interest of Mirov's and receives full treatment in the seventh and eighth chapters. He points out that ehemical evolution may not have run parallel to morphological evolution but that it can provide valuable evidence to supplement morphological data in attempts to explain the relationships between species and provenances of species.

All these threads of enquiry are drawn together in a chapter on taxonomy where the older system based on type specimens is contrasted with the multiple aspeet approach favoured by Mirov and the radically different system of Gaussen which is criticized.

From their fossil history pines are shown to be adapted to seasonal climates with severe dry periods, but unsuited to equatorial zones of high humidity.

The book is well produced. An extensive list of references is given at the end of each chapter and there is an index.

A. F. A. Lamb

\section{HERTFORDSHIRE FLOWERS}

\section{Flora of Hertfordshire}

The Wild Plants of the County of Hertford and the Adjoining Areas included in Watsonian Vice-County 20. By John G. Dony, with a foreword by Edward Salisbury. Pp. $112+56$ maps. (Hitchin: Hitchin Urban District Council, 1967.) 42s. net.

The last Flora of Hertfordshire, that of A. R. Pryor, was published in 1887. It is now amply superseded by Dr Dony's work, very different in style and reflecting the recent trend towards mathematical impartiality seen in other regional floristic studies. We cannot fault the precision with which the records have been assembled, but we may be less confident as to the purpose lying behind such a publication.

The 656 distribution maps, using a $2 \mathrm{~km}$ grid square as unit, are a novel feature of this work, and they invite direct comparison with other mapping methods, such as those used by Good in his studies on the Dorset flora. Whilst documentation is easier with a regular grid, some distribution patterns (for example riparian species) are rather obscured. But, whichever method is used, why map a species distribution at all? Surely the scientific justification is to display a pattern which can be related to possible causative agents, historical or ecological? I feel, reluctantly, that Dony has missed an opportunity here in not attempting to relate distributions to any such controlling factors. As an example, he has not included any geological map. I expect superficial geology to be at least as important as precipitation in a small lowland county, and this is a loss compared with Pryor's work of 80 years ago. Six regions are delimited, precisely mapped and given pseudo-geological names, but they do not coincide with geological outcrops. Furthermore, these regions are not employed in the body of the Flora.

In his previous Flora of Bedfordshire, Dony used "habitat studies", detailed lists of species in well localized sites. These attempt a compromise between the traditional British vagueness in floristic description, and the much greater precision in those emanating from the continent of Europe. They are intended to help in assessing the scale of future vegetational changes. Are they really detailed enough for this? Virtually no data are provided about soils, and the use of "frequent", "occasional" and so on is still too vague. Linking these lists is an account of the main features of plant distribution in Hertfordshire, but the actual factors responsible for this are covered in little more than thirty lines on page 24 . Dony, an acknowledged expert on adventive species, could well have devoted more space to the effects of man in an intensively farmed county, and less to an account of the history of botanical exploration.

Apart from such important and more fundamental issues, $I$ have a few small criticisms to make. There are no definitions of "colonist", "denizen" and so on, it is ambiguous to say that Lathyrus nissolia has "no distribution pattern", Berberis vulgaris does not "cause" wheat rust, and why not omit the grid reference to habitat study 51, instead of including a deliberately falsified version?

As a detailed and reliable factual record of plant distribution, Dony's Flora of Hertfordshire is admirable. But I fear it is only a skeleton. Is there not a danger of overlooking the wood for the trees ... and an account of plant distribution for a card index of impeccably documented dots? D. H. DALBY

\section{EVERYMAN'S GUIDE TO CRIME}

Crime and the Social Structure

By John Barron Mays. New and revised edition. (Society Today and Tomorrow.) Pp. 256. (London: Faber and Faber, Ltd., 1967.) 35s, net.

UNLIKE other books in this series, which report original researches, this volume is a summary review of research into crime, presented within the author's overview of the problem. Its main appeal therefore should be to the socially aware layman, the student and those working in disciplines other than, but related to, sociology. For all, and the latter in particular, it should be salutary. It is well written and very readable.

The analytical framework is simple but persuasive, and would be supported by most sociologists. Our society is crimogenic, in that our social structure produces most crime, which must therefore be regarded as one "normal" response to social stimuli. For an adequate understanding of its causation, and of appropriate remedial action, we must therefore rely primarily on sociology, with the assistance of psychology. But the latter has substantial relevance only to the minority problem of the hardened criminal and the psychopath. The author makes it clear that most crime is confined to the younger age groups, is predominantly against property and not too serious, and is amenable to containment and reduction by effective community action. His preseription mainly emphasizes the desirability of a restructuring and fuller integration of the educational service in the widest sense, embracing the schools, youth service and the corrective institutions for the young. This is admirable as far as it goes, but many sociologists would look for a more extensive approach in view of the author's correct emphasis on social structural analysis in the fullest sense. 